\title{
Patterns of wood carbon dioxide efflux across a 2,000-m elevation transect in an Andean moist forest
}

\author{
Alexandra Zach • Viviana Horna · Christoph Leuschner • \\ Reiner Zimmermann
}

Received: 9 March 2008/Accepted: 3 August 2009/Published online: 26 August 2009

(c) The Author(s) 2009. This article is published with open access at Springerlink.com

\begin{abstract}
During a 1-year measurement period, we recorded the $\mathrm{CO}_{2}$ efflux from stems $\left(R_{\mathrm{S}}\right)$ and coarse woody roots $\left(R_{\mathrm{R}}\right)$ of 13-20 common tree species at three study sites at 1,050, 1,890 and 3,050 m a.s.1. in an Andean moist forest. The objective of this work was to study elevation changes of woody tissue $\mathrm{CO}_{2}$ efflux and the relationship to climate variation, site characteristics and growth. Furthermore, we aim to provide insights into important respiration-productivity relationships of a little studied tropical vegetation type. We expected $R_{\mathrm{S}}$ and $R_{\mathrm{R}}$ to vary with dry and humid season conditions. We further expected $R_{\mathrm{S}}$ to vary more than $R_{\mathrm{R}}$ due to a more stable soil than air temperature regime. Seasonal variation in woody tissue $\mathrm{CO}_{2}$ efflux was indeed mainly attributable to stems. At the same time, temperature played only a small role in triggering variations in $R_{\mathrm{S}}$. At stand level, the ratio of $\mathrm{C}$ release $(\mathrm{g} \mathrm{C}$ $\mathrm{m}^{-2}$ ground area year ${ }^{-1}$ ) between stems and roots varied from $4: 1$ at $1,050 \mathrm{~m}$ to $1: 1$ at $3,050 \mathrm{~m}$, indicating the increasing prevalence of root activity at high elevations. The fraction of growth respiration from total respiration varied between $10(3,050 \mathrm{~m})$ and $14 \%(1,050 \mathrm{~m})$ for stems
\end{abstract}

Communicated by Dan Yakir.

Electronic supplementary material The online version of this article (doi:10.1007/s00442-009-1438-2) contains supplementary material, which is available to authorized users.

A. Zach $(\bowtie) \cdot$ V. Horna · C. Leuschner

Plant Ecology, Albrecht von Haller Institute for Plant Sciences, University of Göttingen, Untere Karspüle 2,

37073 Gottingen, Germany

e-mail: alzac@gmx.de

R. Zimmermann

Institute of Botany, University of Hohenheim, Garbenstrasse 30,

70593 Stuttgart, Germany and between $5(1,050 \mathrm{~m})$ and $30 \%(3,050 \mathrm{~m})$ for roots. Our results show that respiratory activity and hence productivity is not driven by low temperatures towards higher elevations in this tropical montane forest. We suggest that future studies should examine the limitation of carbohydrate supply from leaves as a driver for the changes in respiratory activity with elevation.

Keywords Altitudinal gradient - Coarse root respiration Ecuador - Stem respiration - Tropical montane forest

\section{Introduction}

Tropical montane forests (TMFs) typically show lower aboveground productivity, lower nutrient concentrations in the soil and hence in plant organs, and a slower nutrient turnover than tropical lowland forests (Bruijnzeel and Veneklaas 1998; Soethe et al. 2007; Graefe et al. 2008). Changes in stand structure and functionality have been related to lower temperatures, frequent cloud cover and high atmospheric humidity that limit photosynthesis and transpiration and hence assimilate supply and nutrient uptake at high elevations (Bruijnzeel and Veneklaas 1998; Graham et al. 2003). TMFs extend over a large altitudinal range with a strong corresponding shift in $\mathrm{C}$ allocation from the shoot to the root system with increasing elevation (Bruijnzeel and Veneklaas 1998; Leuschner et al. 2007; Moser 2008). The question remains how TMFs manage to cope with prevailing low light conditions and soil nutrient restrictions.

The study presented here was embedded in a multidisciplinary project conducted in an evergreen TMF in the Andes of southern Ecuador (Beck and Müller-Hohenstein 2001). The aims of this large project were to determine the 
abiotic and biotic compartments of tropical mountain rainforests and their functionality in order to model this complex ecosystem and to formulate sustainable utilisation plans (Beck et al. 2008). In our work we specifically focus on the research of changes in woody tissue $\mathrm{CO}_{2}$ efflux along a 2,000-m elevation transect in response to climate variation, site characteristics and growth. Our first results revealed a sharp decrease in rates of stem $\mathrm{CO}_{2}$ efflux $\left(R_{\mathrm{S}}\right)$ from 1,050 to 3,050 m a.s.l., while coarse woody root $\mathrm{CO}_{2}$ efflux $\left(R_{\mathrm{R}}\right)$ did not decline significantly (Zach et al. 2008). Available data on above- and belowground forest biomass and productivity for the area had shown a concomitant shift in biomass allocation towards root production with increasing elevation (Moser 2008).

In the present study, we addressed four objectives. First, we aimed to examine the annual variability of $R_{\mathrm{S}}$ and $R_{\mathrm{R}}$ at the three different elevations, where we expected $R_{\mathrm{S}}$ to vary more than $R_{\mathrm{R}}$ between seasons, since soil temperature tends to fluctuate less than air temperature. The prevalent climate of the study area is humid and cloudy with an increase in cloud frequency towards higher elevations (Bendix et al. 2006). However, during the course of the measurement year, the effects of a pronounced dry season throughout the study area could be observed. A high sensitivity of this TMF to dry conditions was reported for stem growth (Bräuning et al. 2008) and stomatal conductance (Motzer et al. 2005). Seasonal changes in $\mathrm{CO}_{2}$ efflux are expected as a compensatory response under stress conditions. Plant respiration is largely controlled by temperature (Ryan 1991). Conversely, in light-limited ecosystems like TMFs, temperature effects on respiratory processes might be difficult to separate from shortages in assimilate supply and thus carbohydrate limitation of respiration (Hartley et al. 2006). We found rates of $R_{\mathrm{S}}$ in cases positively or negatively related to temperature or completely uncoupled from the thermal regime, which suggested that temperature was not the only driver of respiration (Zach et al., in review). On a diurnal basis, a tight linkage between photosynthesis and plant respiration has been found for leaves (Dewar et al. 1999; Loveys et al. 2003) and roots (Fitter et al. 1998). In mature boreal forest trees, canopy $\mathrm{C}$ took 1-4 days to become available for root respiration (Ekblad and Högberg 2001). This strong link between photosynthesis and respiration suggested that temperature might play a smaller role in controlling respiration than commonly expected.

The second objective was to estimate growth and maintenance respiration from the monitored $\mathrm{CO}_{2}$ efflux. Here, we expected the fraction of growth respiration to decrease with the decreasing growth activity along the elevation transect. Growth respiration is generally related to the amount of new tissue built (Ryan 1990; Sprugel 1990) and its chemical composition (Penning de Vries
1974; Williams et al. 1987). Maintenance respiration is assumed to scale with tissue $\mathrm{N}$ content (e.g. Waring et al. 1985; Ryan 1990, 1991; Reich et al. 2008), due to the key role protein turnover plays in plant maintenance processes (Penning de Vries 1975). Separating growth from maintenance respiration has greatly improved our knowledge about patterns of $\mathrm{C}$ use in tropical forests, although differentiation is based on several assumptions, such as constant growth rates throughout the year, similar costs for growth across tissues with variable composition (Ryan et al. 1994) and invariable maintenance requirements (Cannell and Thornley 2000).

Thirdly, we determined the patterns of $\mathrm{C}$ use among above- and belowground plant organs with altitude by calculating the $\mathrm{C}$ use efficiency (CUE) as the ratio of biomass production to gross $\mathrm{C}$ fixation (Chambers et al. 2004). The CUE also allows evaluation of the variability in C use among ecosystems (Ryan et al. 1997; Amthor 2000).

Finally, we estimated the net annual C fluxes from stems and coarse woody roots across the montane forest transect. For the extrapolation of efflux data to the stand we integrated previously determined data on stand structural parameters and above- and belowground biomass (Moser 2008).

In our analyses of efflux changes with elevation, we did not consider effects of changes in the species assemblage. Species composition changes considerably along the 2,000$\mathrm{m}$ elevation transect, as do all biotic and abiotic factors. Rates of $R_{\mathrm{S}}$ were also highly variable between species within the three sites (Zach et al. 2008). This might entail a certain confounding of species-specific effects with environmental effects or day-to-day climate variations. However, our overall aim was to present the given vegetation-based differences in $R_{\mathrm{S}}$ and $R_{\mathrm{R}}$ along the elevation gradient by analysing a representative community sub-sample.

\section{Materials and methods}

\section{Study area}

The study was conducted between August 2005 and September 2006 within and close to Podocarpus National Park on the eastern slopes of the southern Ecuadorian Andes. Across an elevation transect of 2,000 m, we chose three forest plots with a maximum distance of $30 \mathrm{~km}$ among them. The sites where the plots were located were a premontane forest at $1,050 \mathrm{~m}$, a lower montane forest at $1,890 \mathrm{~m}$ and an upper montane forest close to the timberline at 3,050 m elevation. Above- and belowground biomass and productivity were determined in a previous study by Moser (2008). Detailed site characteristics are given in Leuschner et al. (2007) and Moser (2008; Table 1). 
Table 1 Site characteristics of the three forest stands at 1,050, 1,890 and 3,050 m a.s.l., where efflux measurements were conducted (mean \pm 1 SE; Moser 2008)

\begin{tabular}{|c|c|c|c|}
\hline & $1,050 \mathrm{~m}$ & $1,890 \mathrm{~m}$ & $3,050 \mathrm{~m}$ \\
\hline Forest type & Premontane & Lower montane & Upper montane \\
\hline Coordinates & $04^{\circ} 06^{\prime} 54^{\prime \prime} \mathrm{S}, 78^{\circ} 58^{\prime} 02^{\prime \prime} \mathrm{W}$ & $03^{\circ} 58^{\prime} 345^{\prime \prime} \mathrm{S}, 79^{\circ} 04^{\prime} 648^{\prime \prime} \mathrm{W}$ & $04^{\circ} 06^{\prime} 711^{\prime \prime} \mathrm{S}, 79^{\circ} 10^{\prime} 581^{\prime \prime} \mathrm{W}$ \\
\hline Inclination $\left(^{\circ}\right)$ & 26 & 31 & 27 \\
\hline Canopy height (m) & 31.8 & 18.9 & 9.0 \\
\hline Stem density (no. ha ${ }^{-1}$ ) & 968 & 2,333 & 8,317 \\
\hline Wood density $\left(\mathrm{g} \mathrm{cm}^{-3}\right)$ & $0.64(0.03)$ & $0.60(0.04)$ & $0.69(0.03)$ \\
\hline $\mathrm{SAI}^{\mathrm{a}}\left(\mathrm{m}^{2} \mathrm{~m}^{-2}\right)$ & 0.52 & 0.51 & 0.52 \\
\hline
\end{tabular}

${ }^{a}$ Stem area index $(S A I)$ derived from a cone-shaped tree model (see S2)

The study area experiences a humid climate with a rain peak from April to July and a less humid period between November and February (Bendix et al. 2006). While easterly winds are responsible for the prevailing humid climate for most of the year, westerly foehn winds frequently cause dry and sunny days between November and February. Foehn winds were especially pronounced during our measurement period between October and December 2005, causing a marked dry season throughout the study area.

\section{Sampling}

We measured rates of $R_{\mathrm{S}}$ on 13-21 canopy trees per plot. Trees from 13 to 20 different species belonging to the ten to 11 most abundant families were chosen (see electronic supplement, S1). The range of diameter at breast height (DBH) was $8.7-43.8 \mathrm{~cm}$ at $1,050 \mathrm{~m}, 3.0-26.5 \mathrm{~cm}$ at $1,890 \mathrm{~m}$, and $2.5-17.7 \mathrm{~cm}$ at $3,050 \mathrm{~m}$, which represented the average tree size distribution at each elevation. In addition, four to eight randomly selected coarse woody roots (diameter: $1-4 \mathrm{~cm}$ ) growing $5-10 \mathrm{~cm}$ below the soil surface were measured at each plot. Species identification for coarse roots was not possible. The trees were equipped with manual dendrometer bands (accuracy: $0.01 \mathrm{~cm}$ ) for monitoring stem diameter increment at $1.3 \mathrm{~m}$ stem height (DBH). The annual diameter increment was derived from dendrometer data at the beginning of the study and upon completion of the last measurement campaign. Coarse root diameter was measured manually in the middle of the section enclosed by the measurement chamber at the beginning of the study.

$\mathrm{CO}_{2}$ efflux measurements

Within the measurement year, we conducted four measurement campaigns at each forest plot, where we monitored rates of $R_{\mathrm{S}}$ and $R_{\mathrm{R}}$. We monitored $R_{\mathrm{S}}$ and $R_{\mathrm{R}}$ for a complete 24 -h period every time, with values being automatically recorded every half hour. Each campaign lasted for 15-20 days with the measurement system rotating between the three plots.

The annual cycle included a pronounced dry season between October and December 2005 (D1), and three measurement campaigns with more typical humid climate conditions between August and September 2005 (H1) and from March to September 2006 (H2 and H3; Fig. 1). The measurement campaign at 1,890 m in April 2006 (H2) was done twice; we repeated measurements when the first unusually dry part of April (H2dry) was followed by more typical rainy weather (H2wet; Fig. 1). Due to equipment failure at the beginning of the campaigns in August 2005, we excluded the dataset of the first campaign (H1) from the site at $3,050 \mathrm{~m}$, and the first measurements on coarse roots (H1) at 1,890 m from further analysis.

Rates of $\mathrm{CO}_{2}$ efflux were measured with a mobile sixchamber respiration system (ANARESY 2; Walz, Effeltrich, Germany) with an integrated infrared gas analyser for $\mathrm{CO}_{2}$ and $\mathrm{H}_{2} \mathrm{O}$ (LI-7000; Li-Cor, Lincoln, Neb.) running in differential mode. For details on the technical equipment see Zach et al. (2008). For stems, a tightly fitted, transparent Plexiglas chamber $\left(95 \mathrm{~cm}^{3}\right)$ of half-cylindrical shape was fixed at DBH; sections (length: $15 \mathrm{~cm}$ ) of intact coarse roots were enclosed in cylindrical Plexiglas chambers $\left(474 \mathrm{~cm}^{3}\right)$. Bark photosynthesis could be excluded (unpublished data). Light incidence at the position where chambers were installed was minimal; hence, chamber overheating did not play a role (personal observation). Before installing the chambers, the stem or root surface was freed from mosses, lichens, algae, soil or any other material that could mean a source or sink for $\mathrm{CO}_{2}$ efflux. When cleaning the surface, we used a soft brush to avoid damaging the stem or root bark. Roots were recovered after measurements and left until the next campaign.

Rates of $\mathrm{CO}_{2}$ efflux were calculated as:

$R=D\left[\mathrm{CO}_{2}\right] \times F / \mathrm{Ac}$

where $R$ is the $\mathrm{CO}_{2}$ efflux rate $\left(\mu \mathrm{mol} \mathrm{CO}_{2} \mathrm{~m}^{-2} \mathrm{~s}^{-1}\right), D$ $\left[\mathrm{CO}_{2}\right]$ is the difference between ambient (reference gas) 

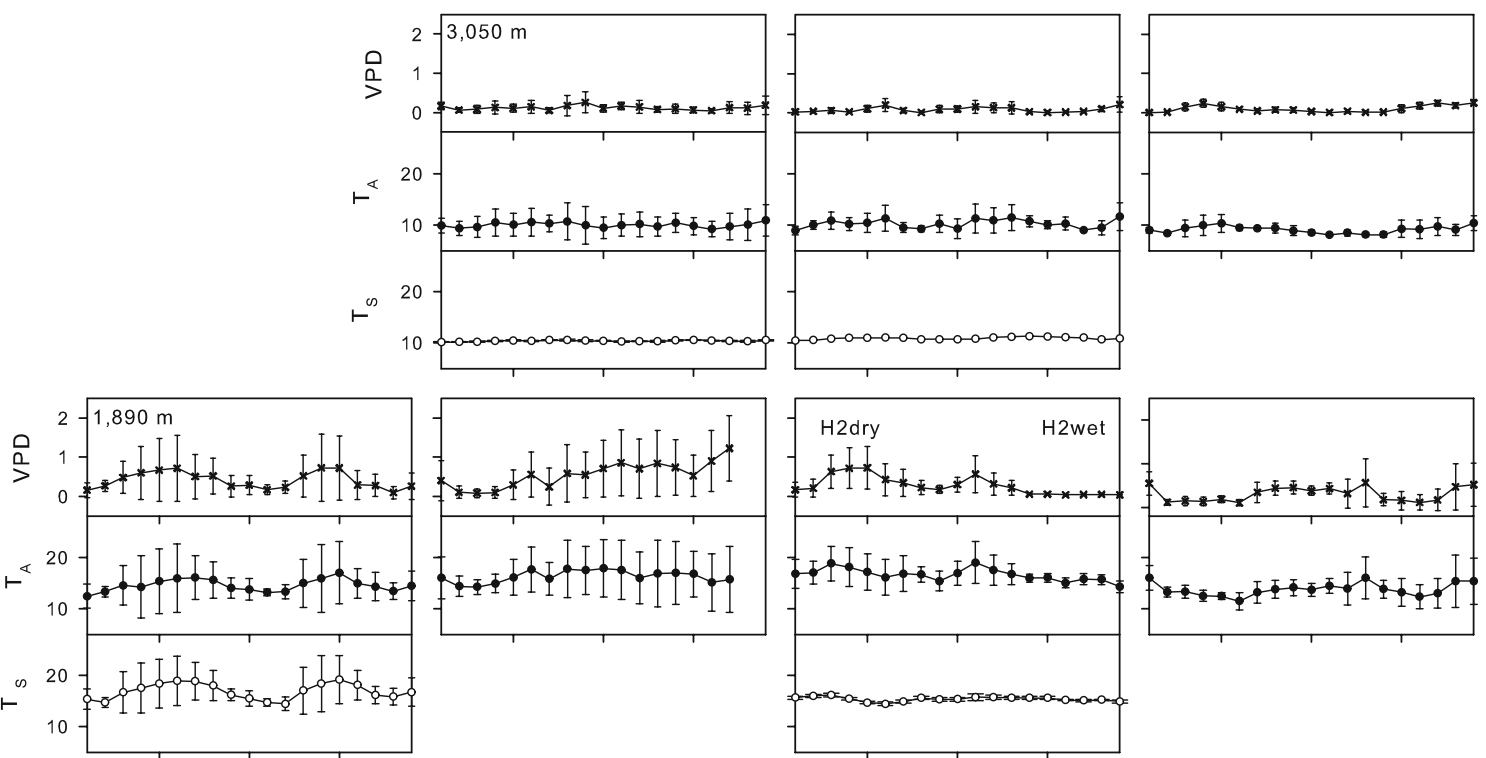

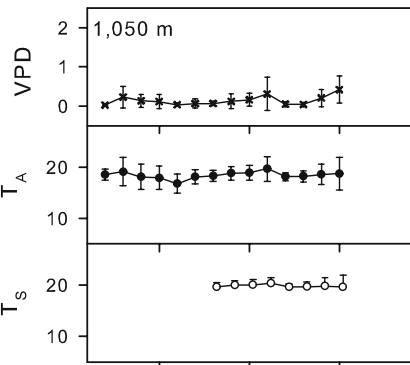

$\mathrm{H} 1,2005$

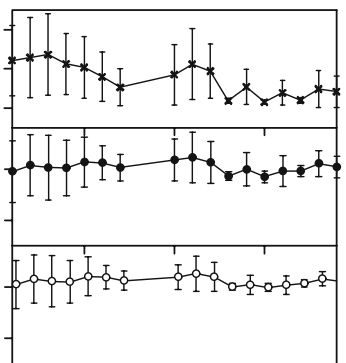

D1, 2005

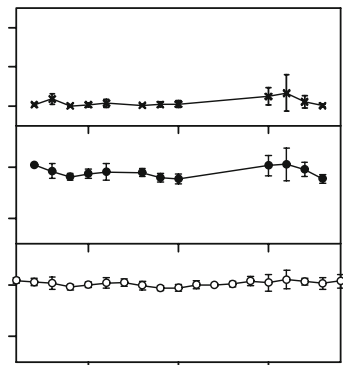

$\mathrm{H} 2,2006$

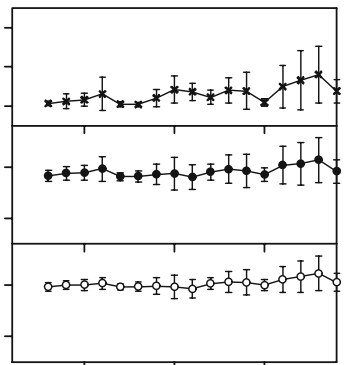

H3, 2006
Fig. 1 Daily climate conditions during the measurement campaigns conducted between August 2005 and September 2006 at the three study plots at 1,050, 1,890, and $3,050 \mathrm{~m}$ a.s.l. At each plot, measurements were made during one dry season period between October and December 2005 (D1) and three humid season periods between August and September 2005 (H1), March and April 2006 (H2) and July and September 2006 (H3). At 1,890 m, the

and chamber (sample gas) $\mathrm{CO}_{2}$ concentration, $F$ is the molar air flow rate $\left(\mathrm{mol} \mathrm{s}^{-1}\right)$ which passes through the chamber, and Ac is the surface area $\left(\mathrm{m}^{2}\right)$ of the enclosed stem or root segment. Due to a better relation of the $\mathrm{CO}_{2}$ efflux to surface area than to volume, we based our efflux rates on the surface area (Zach et al. 2008). Although we are aware of $\mathrm{CO}_{2}$ potentially being transported to or carried away from the point of measurement with the xylem sap flow (e.g. Teskey and McGuire 2002, 2007), we assumed measured rates of $\mathrm{CO}_{2}$ efflux to originate from local tissue respiration.

\section{Stand microclimate}

We recorded air temperature and relative air humidity at 2-m height inside the stand using a Rotronic sensor (Rotronic, Bassersdorf, Switzerland) connected to the data measurement campaign $\mathrm{H} 2$ was done twice; we repeated measurements when the unusually dry part of early April (H2dry) was followed by more typical rainy weather $(H 2 w e t)$. For each campaign the daily mean $( \pm 1 \mathrm{SD})$ of vapour pressure deficit $(V P D ; \mathrm{kPa})$, air temperature $\left(T_{A} ;{ }^{\circ} \mathrm{C}\right)$ and soil temperature $\left(T_{S} ;{ }^{\circ} \mathrm{C}\right)$ were given as far as available. $T_{\mathrm{S}}$ was measured in the middle of the organic layer by S. Graefe (unpublished data)

logger of the ANARESY system (CR 10; Campbell Scientific, Logan, Utah).

Tissue temperature was monitored in two to three randomly chosen trees at 1,050 and $1,890 \mathrm{~m}$ (DBH: 15-20 cm) and at 3,050 m (DBH: $10-15 \mathrm{~cm})$ and in two to three coarse woody roots (diameter: $2-4 \mathrm{~cm}$ ) per plot, which were not used for $\mathrm{CO}_{2}$ efflux measurements. Thermocouples for tissue temperature (diameter, $3 \mathrm{~mm}$; length, $20 \mathrm{~mm}$; Siemens, Munich) were installed at 10-mm depth in the stem wood (at DBH) and in coarse woody roots growing 5-10 cm under the soil surface. The tissue temperature data were logged from July 2006 (unpublished data) and were used to extrapolate the stem $\left(T_{\mathrm{TS}}\right)$ and coarse root tissue temperatures $\left(T_{\mathrm{TR}}\right)$ of our measurement period (August 2005-September 2006). We related the stem and coarse root tissue temperature measurements to air temperature and used these relationships to calculate 
$T_{\mathrm{TS}}$ and $T_{\mathrm{TR}}$ of the measurement campaigns of each plot from site microclimate records.

\section{Wood samples}

After measurements, we extracted wood cores from all tree individuals using an increment borer $(5 \mathrm{~mm}$ diameter; Haglöf, Långsele, Sweden) by coring horizontally from the bark to the centre of the bole. Cores were taken in the section where $\mathrm{CO}_{2}$ efflux was measured on the stem. Root samples were taken by cutting segments of 3-4 cm length. We recorded the fresh weight of all samples and calculated sample volume from sample length and diameter. After drying the samples to constant weight at $70^{\circ} \mathrm{C}$, we determined wood density as the dry mass per volume of fresh wood. The dry samples were analysed for their contents of $\mathrm{C}$ and $\mathrm{N}$ with a CNS elementary analyser (Vario-EL-III; Elementaranalysesysteme, Hanau, Germany; data not shown).

Growth and maintenance respiration

We calculated growth respiration $\left(R_{\mathrm{g}}\right)$ of the tree stems $\left(R_{\mathrm{Sg}}\right)$ following Ryan et al. (1994):

$$
\begin{aligned}
R_{\mathrm{g}}= & 0.248 \times p \times V_{\mathrm{G}} \times\left(\mathrm{C}_{\text {sample }} \times\left(10^{6} \mu \mathrm{mol} / 12 \mathrm{~g} \mathrm{C}\right)\right. \\
& \left.\times\left(1 / 365 \text { days } \times 86400 \mathrm{~s} \mathrm{day}^{-1}\right)\right)
\end{aligned}
$$

where 0.248 is the estimated mean $\mathrm{C}$ cost per gram $\mathrm{C}$ incorporated (Meir and Grace 2002), $p$ is the wood specific gravity $\left(\mathrm{g} \mathrm{cm}^{-3}\right), V_{\mathrm{G}}$ is the volume of annual wood growth under the measurement chamber $\left(\mathrm{cm}^{3} \mathrm{~m}^{-2}\right)$ and $\mathrm{C}_{\text {sample }}$ is the wood $\mathrm{C}$ content ( $\mathrm{g} \mathrm{C} \mathrm{g}$ biomass $^{-1}$ ). The annual increment of the woody tissue under the chamber was estimated from our own diameter increment measurements and wood specific gravity as determined for each tree stem from the wood cores (data not shown). Growth was assumed to be constant throughout the year (Ryan et al. 1994). We then calculated the production of woody biomass from the sample $\mathrm{C}$ content and by assuming an ash-free dry matter content of $99.3 \%$ (Ryan et al. 1994). Maintenance respiration $\left(R_{\mathrm{m}}\right)$ is estimated by subtracting the calculated growth respiration from total $\mathrm{C}$ efflux rates (Ryan et al. 1994).

Wood construction costs are likely to change with increasing elevation as a result of changes in the chemical composition and wood density (Poorter 1994; Bruijnzeel and Veneklaas 1998), but we are not aware of experimentally determined data on metabolic requirements for wood construction at different elevations or under different temperatures. Along the transect from 1,050 to $3,050 \mathrm{~m}$, wood density increased slightly, though not significantly (Moser 2008; Table 1). We therefore suppose that the uncertainty associated with possible changes in the costs for wood growth with altitude did not seriously affect our overall conclusion and we used Eq. 2 to calculate growth respiration along the entire elevation transect.

Estimates of coarse root growth respiration $\left(R_{\mathrm{Rg}}\right)$ were based on mean annual rates of $R_{\mathrm{R}}$ converted to a volume basis ( $\mu \mathrm{mol} \mathrm{CO} \mathrm{CO}_{2} \mathrm{~m}^{-3}$ ) and annual coarse root biomass production. Annual coarse root production derived from monthly diameter increment measurements of 20 randomly selected roots per site (diameter: $3-32 \mathrm{~cm}$ ) using manual diameter tapes (Moser 2008). Coarse root biomass was assumed to contain $50 \% \mathrm{C}$ in the ash-free dry matter (Edwards et al. 1980) and growth respiration was assumed to account for $24.8 \%$ of the $\mathrm{C}$ content of the dry matter production (Meir and Grace 2002).

Extrapolation of $R_{\mathrm{S}}$ and $R_{\mathrm{R}}$

For each elevation, we calculated the annual stand $\mathrm{C}$ efflux from stem wood by combining measured rates of $R_{\mathrm{S}}$ with forest structural data collected in a previous study (Moser 2008; see S2). Estimates of the stand coarse root $\mathrm{C}$ efflux derived from mean annual efflux rates $\left(R_{\mathrm{R}} ; \mu \mathrm{mol}\right.$ $\left.\mathrm{CO}_{2} \mathrm{~m}^{-3} \mathrm{~s}^{-1}\right)$ and data on the standing coarse root biomass stock ( $\mathrm{g} \mathrm{C} \mathrm{m}^{-2}$ ground area; from Moser 2008; see S2).

C use efficiency

We calculated the CUE of stems and coarse roots as the ratio of stem or coarse root $\mathrm{C}$ production to gross $\mathrm{C}$ fixation (e.g. stem production $+R_{\mathrm{S}}$; coarse root production $+R_{\mathrm{R}}$; Chambers et al. 2004). This ratio is dimensionless. We used our data on $\mathrm{CO}_{2}$ efflux as well as our own stem diameter increment measurements to determine CUE of stems and data on annual coarse root production for the CUE of coarse roots (Moser 2008). C used for storage was not taken into account.

Statistical analysis

Diurnal mean rates of $R_{\mathrm{S}}$ of each measured tree were averaged to calculate stand means for each campaign. Mean rates of the four measurement campaigns per plot were averaged to annual means. Differences between mean rates of $R_{\mathrm{S}}$ and $R_{\mathrm{R}}$ of the different measurement campaigns conducted at each site $(1,050,1,890,3,050 \mathrm{~m})$ were tested for significance using ANOVA and mean rates of diurnal $\mathrm{CO}_{2}$ efflux of each measured stem or coarse root were used as replicates. For the sites at 1,050 and $1,890 \mathrm{~m}$, the daily mean $R_{\mathrm{S}}$ values of the individual trees were $\log$ transformed prior to ANOVA to achieve homogeneity of variances (Scheffé test, $P<0.05$ ). Data of $\mathrm{R}_{\mathrm{S}}$ of individual 
trees at 3,050 m matched parametric assumptions without transformation. We tested for significant differences in $R_{\mathrm{R}}$ between the measurement campaigns at each site using the same procedure as for $R_{\mathrm{S}}$ (Scheffé test, $P<0.05$ ). Data of $R_{\mathrm{R}}$ matched parametric assumptions without transformation. We calculated coefficients of variation $(\mathrm{CV}$; i.e. SD expressed as a percentage of the mean) to compare the relative amount of variation in $R_{\mathrm{S}}$ and $R_{\mathrm{R}}$ among the four measurement campaigns per plot. We used the coefficient of determination $\left(r^{2}\right)$ to quantify the influence of predictor variables (basal area, stem increment, $\mathrm{N}$ content) on diurnal mean rates of $R_{\mathrm{S}}$ of each measured tree.

\section{Results}

Seasonality of wood $\mathrm{CO}_{2}$ efflux

Mean rates of $R_{\mathrm{S}}$ at $1,050 \mathrm{~m}$ were significantly higher during D1 compared to the more humid campaigns $\mathrm{H} 2$ and H3 (Table 2). Differences between campaigns were not significant at the sites at 1,890 and $3,050 \mathrm{~m}$. Among tree individuals of the three sites, the variability in rates of $R_{\mathrm{S}}$ was high during all campaigns as indicated by the $\mathrm{CV}$ (Table 2). Nevertheless, highest mean rates of $R_{\mathrm{S}}$ were measured during the driest and warmest period of the measurement year at all three sites (D1 and H2dry; Table 2), while minimum rates of $R_{\mathrm{S}}$ were measured under more humid conditions $(\mathrm{H} 1-\mathrm{H} 3)$. This seasonal contrast was especially pronounced at $1,890 \mathrm{~m}$ (Table 2; Fig. 1). While high rates of $R_{\mathrm{S}}$ were recorded during the exceptionally dry part of early April (H2dry) with weather conditions comparable to the D1 campaign, mean $R_{\mathrm{S}}$ dropped by $65 \%$ during the rainy second part of the month (H2wet; Table 2; Fig. 1). Annual mean rates of $R_{\mathrm{S}}$ decreased along the elevation gradient (Table 3 ). Elevation differences were most pronounced during D1 and least marked during $\mathrm{H} 1, \mathrm{H} 2$ and $\mathrm{H} 3$ (Table 2). Mean annual rates of $R_{\mathrm{R}}$ decreased with increasing altitude (Table 3 ). Among measurement campaigns rates of $R_{\mathrm{R}}$ did not show a seasonal trend at the three sites (Table 2).

Growth and maintenance respiration

In parallel with the mean annual stem diameter growth rates, mean absolute values of $R_{\mathrm{Sg}}$ decreased continuously with increasing elevation (Table 3 ). However, the average proportion of $R_{\mathrm{Sg}}$ from total $R_{\mathrm{S}}$ decreased only slightly with altitude and accounted for $14 \%$ of total $R_{\mathrm{S}}(0.11 \pm$ $0.12 \mu \mathrm{mol} \mathrm{CO}_{2} \mathrm{~m}^{-2}$ surface area $\left.\mathrm{s}^{-1} ; \pm \mathrm{SD}\right)$ at $1,050 \mathrm{~m}$, for $13 \%(0.05 \pm 0.06)$ at $1,890 \mathrm{~m}$ and for $10 \%$ $(0.01 \pm 0.02)$ at $3,050 \mathrm{~m}$. We did not find any correlation between stem maintenance respiration $\left(R_{\mathrm{Sm}}\right)$ and tissue $\mathrm{N}$ content at the sites (data not shown). Mean annual $R_{\mathrm{S}}$ was weakly correlated with annual wood increment at $1,890 \mathrm{~m}$ ( $\left.r^{2}=0.21, P=0.049\right)$, whereas no relationship was found at 1,050 and $3,050 \mathrm{~m}$ (data not shown). Annual coarse root production increased from $8.44 \mathrm{~g} \mathrm{C} \mathrm{m}^{-2}$ ground area year ${ }^{-1}$ at $1,050 \mathrm{~m}$ to $44.20 \mathrm{~g} \mathrm{C} \mathrm{m}^{-2}$ ground area year ${ }^{-1}$ at 3,050 $\mathrm{m}$ (Moser 2008; Table 3). At the same time, the fraction of $R_{\mathrm{Rg}}$ from total $R_{\mathrm{R}}$ continuously increased with elevation from $5 \%$ at $1,050 \mathrm{~m}$ to $30 \%$ at 3,050 $\mathrm{m}$ (Table 3 ).

Scaling $R_{\mathrm{S}}$ and $R_{\mathrm{R}}$

Annual stand C efflux from stems was 167, 103 and $38 \mathrm{~g} \mathrm{C}$ $\mathrm{m}^{-2}$ ground area year ${ }^{-1}$ at $1,050,1,890$ and $3,050 \mathrm{~m}$, respectively (Table 4). Stand $\mathrm{C}$ efflux from coarse roots was 41,19 and $37 \mathrm{~g} \mathrm{C} \mathrm{m}^{-2}$ ground area year ${ }^{-1}$ at 1,050 , 1,890 and $3,050 \mathrm{~m}$, respectively.

C use efficiency

We calculated a declining stem CUE of $0.46,0.30$ and 0.16 at 1,050, 1,890 and 3,050 m, respectively. The coarse root CUE increased along the transect from 0.17 at $1,050 \mathrm{~m}$ and 0.37 at $1,890 \mathrm{~m}$ to 0.55 at $3,050 \mathrm{~m}$ (Table 3 ).

\section{Discussion}

Seasonality of wood $\mathrm{CO}_{2}$ efflux across the elevation transect

We found rates of $R_{\mathrm{S}}$ to respond to seasonal climate variations, while $R_{\mathrm{R}}$ did not differ significantly between dry and humid periods. Few comparable studies on the seasonal variability of $R_{\mathrm{S}}$ in evergreen forests exist. In a wet tropical lowland forest, rates of $R_{\mathrm{S}}$ from evergreen trees showed no indication of seasonality (Cavaleri et al. 2006). Along an elevation transect in TMFs in Puerto Rico, the variability of $R_{\mathrm{S}}$ among consecutive months was not more than $10 \%$ and highest rates were measured under dry forest conditions (Harris et al. 2008). In our study, periods of highest $R_{\mathrm{S}}$ were exceptionally dry and warm, but rates of $R_{\mathrm{S}}$ were not directly related to temperature. During the warmest campaign, D1, plotting $R_{\mathrm{S}}$ against temperature yielded a highly scattered picture, when all trees per study site were combined ( $r^{2}=0.017-0.064$; Zach et al. 2008). When diurnal courses of $R_{\mathrm{S}}$ were plotted individually against the respective diurnal temperature course, the response was very weak in most cases (data not shown). Consequently we do not suspect a confounding effect of species and tree individuals with day to day temperature variation. On cloudless days, the daily sum of global radiation measured did not differ between 1,050 and 
Table 2 Mean rates of stem $\left(R_{\mathrm{S}}\right)$ and coarse root $\mathrm{CO}_{2}$ release $\left(R_{\mathrm{R}} ; \mu \mathrm{mol} \mathrm{CO} \mathrm{CO}^{-2}\right.$ surface area s $\left.{ }^{-1} ; \pm 1 \mathrm{SD}\right)$ of the three study plots at 1,050 , 1,890 and 3,050 m a.s.l. during a dry season $(D 1)$ and three humid season measurement campaigns $(H 1, H 2, H 3)$

\begin{tabular}{|c|c|c|c|}
\hline & $1,050 \mathrm{~m}$ & $1,890 \mathrm{~m}$ & $3,050 \mathrm{~m}$ \\
\hline \multicolumn{4}{|l|}{ Stems } \\
\hline H1 & $0.97 \pm 0.41 \mathrm{ab}(41.9)$ & $0.51 \pm 0.53$ a (102.5) & - \\
\hline D1 & $1.38 \pm 0.88$ a $(63.6)$ & $0.76 \pm 0.52$ a $(67.7)$ & $0.21 \pm 0.12$ a (58.6) \\
\hline H2dry & - & $0.80 \pm 0.53$ a (66.3) & - \\
\hline H2wet & $0.55 \pm 0.29$ bc $(52.2)$ & $0.28 \pm 0.21$ a $(76.2)$ & $0.20 \pm 0.25$ a (124.7) \\
\hline H3 & $0.54 \pm 0.32 \mathrm{c}(59.1)$ & $0.38 \pm 0.33$ a (86.8) & $0.17 \pm 0.14$ a $(84.5)$ \\
\hline \multicolumn{4}{|c|}{ Coarse roots } \\
\hline H1 & $0.37 \pm 0.27$ a (74.9) & - & - \\
\hline D1 & $0.34 \pm 0.23 \mathrm{a}(68.1)$ & $0.28 \pm 0.20$ a (70.7) & $0.20 \pm 0.15$ a $(72.1)$ \\
\hline H2dry & - & $0.23 \pm 0.24$ a $(104.3)$ & - \\
\hline H2wet & $0.37 \pm 0.26$ a (70.8) & $0.26 \pm 0.22$ a $(82.7)$ & $0.19 \pm 0.14$ a (75.7) \\
\hline H3 & $0.37 \pm 0.13 \mathrm{a}(36.2)$ & $0.26 \pm 0.19$ a $(73.7)$ & $0.10 \pm 0.13$ a (125.1) \\
\hline
\end{tabular}

At 1,890 m, the measurement campaign $\mathrm{H} 2$ was done twice; we repeated measurements when the first unusually dry part of April (H2dry) was followed by more typical rainy weather (H2wet). Coefficient of variation (\%) of mean rates of $R_{\mathrm{S}}$ and $R_{\mathrm{R}}$ is given in parentheses. Different letters indicate significant differences (Scheffé, $P<0.05$ ) between measurement campaigns for mean rates of $R_{\mathrm{S}}$ and $R_{\mathrm{R}}$ within each study plot

Table 3 Mean annual rates of $\mathrm{CO}_{2}$ release $\left(R ; \mu \mathrm{mol} \mathrm{CO} \mathrm{CO}^{-2}\right.$ surface area s${ }^{-1} ; \pm 1 \mathrm{SD}$ in parentheses) from stems and coarse roots, annual stem diameter increment $\left(\mathrm{cm}_{\text {year }}{ }^{-1}\right.$; mean $\left.\pm 1 \mathrm{SD}\right)$ and coarse root biomass growth $\left(\mathrm{g} \mathrm{C} \mathrm{m}^{-2}\right.$ ground area year ${ }^{-1}$; from Moser 2008$)$ at the three study plots at 1,050, 1,890 and 3,050 $\mathrm{m}$ a.s.l.

\begin{tabular}{|c|c|c|c|c|c|c|c|}
\hline Sites & $R$ & Growth & $R_{\mathrm{g}}\left(\mathrm{g} \mathrm{C} \mathrm{m}^{-2}\right.$ year $\left.^{-1}\right)$ & $R_{\mathrm{m}}\left(\mathrm{g} \mathrm{C} \mathrm{m}^{-2}\right.$ year $\left.^{-1}\right)$ & $R_{\mathrm{g}}(\%)$ & $R_{\mathrm{m}}(\%)$ & CUE \\
\hline \multicolumn{8}{|l|}{ Stems } \\
\hline $1,050 \mathrm{~m}$ & $0.86(0.40)$ & $0.13(0.16)$ & 23.7 & 143.4 & 14 & 86 & 0.46 \\
\hline $1,890 \mathrm{~m}$ & $0.54(0.23)$ & $0.05(0.05)$ & 13.6 & 89.1 & 13 & 87 & 0.30 \\
\hline $3,050 \mathrm{~m}$ & $0.19(0.03)$ & $0.01(0.03)$ & 3.9 & 33.8 & 10 & 90 & 0.16 \\
\hline \multicolumn{8}{|c|}{ Coarse roots } \\
\hline $1,050 \mathrm{~m}$ & $0.36(0.09)$ & 8.44 & 2.1 & 38.8 & 5 & 95 & 0.17 \\
\hline $1,890 \mathrm{~m}$ & $0.26(0.04)$ & 11.40 & 2.8 & 16.4 & 15 & 85 & 0.37 \\
\hline $3,050 \mathrm{~m}$ & $0.16(0.01)$ & 44.20 & 11.0 & 25.8 & 30 & 70 & 0.55 \\
\hline
\end{tabular}

Growth $\left(R_{\mathrm{g}}\right)$ and maintenance respiration $\left(R_{\mathrm{m}}\right)$ of stems and coarse roots are given in annual rates $\left(R_{\mathrm{g}}, R_{\mathrm{m}} ; \mathrm{g} \mathrm{C} \mathrm{m}^{-2}\right.$ ground area year $\left.^{-1}\right)$ and as percentage $(\%)$ of total stem and coarse root $\mathrm{CO}_{2}$ release. $\mathrm{C}$ use efficiency $(C U E)$ is calculated as $\mathrm{g} \mathrm{C}$ produced per $\mathrm{g} \mathrm{C}$ respired plus $\mathrm{g} \mathrm{C}$ produced $\left(\mathrm{g} \mathrm{g}^{-1}\right)$. For other abbreviations, see Table 2

3,050 $\mathrm{m}$ (Unger 2005). However, cloud frequency and precipitation increased considerably with increasing elevation in the study area (Bendix et al. 2006; Table 4). At the same time the leaf area index declined from 6.0 at $1,050 \mathrm{~m}$ to 2.2 at $3,050 \mathrm{~m}$ (Moser 2008; Table 4). Our results seem to indicate that primarily light-limited ecosystems like TMFs might be more responsive to variation in incoming solar radiation, and hence carbohydrate supply for respiration, than to differences in the diurnal temperature regime. A primary linkage of allocated assimilates to plant respiration has not been reported yet for tree stems, but was evidenced for roots (Ekblad and Högberg 2001) and leaves (Dewar et al. 1999; Loveys et al. 2003) of woody perennials.

Rates of $R_{\mathrm{R}}$ did not vary significantly between campaigns. To our knowledge, there are no comparable studies on $R_{\mathrm{R}}$ in TMFs. In strongly seasonal northern latitude environments, root respiration was significantly affected by season and temperature (Desrochers et al. 2002), but also uncoupled from soil temperature (Burton and Pregitzer 2003). Explanations for these discrepancies included a certain temperature threshold below which a temperature response of root respiration does not occur (Bryla et al. 2001) or a time lag between apparent rates of $R_{R}$ and soil temperature (Atkin et al. 2000). In our study, less variation in $R_{\mathrm{R}}$ most likely resulted from fewer fluctuations in soil than air temperature throughout seasons at the same depth roots were measured (Fig. 1). Furthermore, C was preferably allocated to aboveground organs at $1,050 \mathrm{~m}$ and to the fine root system at 3,050 m (Leuschner et al. 2007), which might uncouple coarse root physiology from seasonal effects along our gradient. 
Table 4 Annual wood (stem only) C release $\left(R_{\text {Sannual }}\right.$; $\mathrm{g} \mathrm{C} \mathrm{m}^{-2}$ ground area year $\left.{ }^{-1}\right)$, stem biomass $\left(\mathrm{g} \mathrm{C} \mathrm{m}^{-2}\right.$ ground area) and selected site characteristics of 11 tropical, three temperate and one boreal forest site (altitude in $\mathrm{m}$ a.s.l.)

\begin{tabular}{|c|c|c|c|c|c|c|c|c|c|c|c|}
\hline Altitude & Forest type & Site & $P$ & $T_{\text {Air }}$ & LAI & $\begin{array}{l}\text { Basal } \\
\text { area }\end{array}$ & $h_{\text {mean }}$ & $R_{\text {Sannual }}$ & $\begin{array}{l}\text { Stem } \\
\text { biomass }\end{array}$ & $\begin{array}{l}\mathrm{R}_{\mathrm{S}} / \text { stem } \\
\text { biomass }\end{array}$ & Source \\
\hline 1,050 & Premontane & Ecuador & 1,900 & 19.4 & 6.0 & 33.6 & 15.6 & 167 & 13,915 & 0.012 & This study \\
\hline 1,890 & Montane & Ecuador & 2,200 & 15.7 & 5.7 & 36.9 & 10.1 & 103 & 8,160 & 0.013 & This study \\
\hline 3,050 & Upper montane & Ecuador & 4,500 & 9.4 & 2.2 & 42.2 & 5.2 & 38 & 5,430 & 0.007 & This study \\
\hline 100 & Lowland & $\begin{array}{r}\text { Puerto } \\
\text { Rico }\end{array}$ & 2,330 & 23 & & & & 740 & & & Harris et al. (2008) \\
\hline \multirow[t]{3}{*}{1,075} & Elfin type & $\begin{array}{r}\text { Puerto } \\
\text { Rico }\end{array}$ & 4,500 & 19 & & & & 210 & & & \\
\hline & Lowland, secondary & Cameroon & 1,520 & 24.5 & 4.4 & & 36 & 214 & $8,700^{\mathrm{a}}$ & $0.030^{\mathrm{a}}$ & Meir and Grace (2002) \\
\hline & Lowland & Brazil & 2,200 & 25.5 & 5.5 & 29 & 30 & 390 & 11,700 & 0.033 & Meir et al. (1996) \\
\hline $50-150$ & $\begin{array}{l}\text { Lowland, old } \\
\text { growth }\end{array}$ & Brazil & 2,900 & 26.7 & 5.7 & & & 420 & & & Chambers et al. (2004) \\
\hline 50 & Wet, old growth & Costa Rica & 3,880 & 26.2 & 6.5 & & & $\begin{array}{r}220- \\
360\end{array}$ & 12,450 & $0.018-0.029$ & Ryan et al. (1994) \\
\hline \multirow[t]{5}{*}{$37-150$} & Wet, old growth & Costa Rica & 4,000 & 26 & 6.5 & 24 & 20 & 508 & 8,100 & 0.063 & Cavaleri et al. (2004) \\
\hline & Wood $<10 \mathrm{~cm}$ & & & & & & & 359 & 1,200 & 0.299 & \\
\hline & Wood $>10 \mathrm{~cm}$ & & & & & & & 149 & 6,900 & 0.022 & \\
\hline & $\begin{array}{l}\text { Sahelian-shrub- } \\
\text { fallow }\end{array}$ & Niger & 562 & $33-41$ & 0.6 & & 2.2 & 47.2 & & & Levy and Jarvis (1998) \\
\hline & Temperate, mixed & Alberta & 1,400 & $5-23$ & 4.9 & 20.1 & 26 & 196 & 5,710 & 0.034 & Mahli et al. (1999) \\
\hline \multirow[t]{3}{*}{300} & Temperate, beech & France & 820 & 9.2 & 5.6 & & 13 & 225 & & & Damesin et al. (2001) \\
\hline & Temperate, mixed & Tennessee & 1,400 & 13.3 & 5.0 & 21.5 & & $\begin{array}{r}149- \\
204\end{array}$ & 6,500 & $0.023-0.031$ & $\begin{array}{l}\text { Edwards and Hanson } \\
\text { (1996) }\end{array}$ \\
\hline & Boreal, coniferous & Canada & 400 & $\begin{array}{l}-20 \text { to } \\
17\end{array}$ & 3.3 & 31.5 & 9 & 87 & 3,630 & 0.024 & Lavigne and Ryan (1997) \\
\hline
\end{tabular}

Standing wood biomass is assumed to contain $50 \% \mathrm{C}$. Annual precipitation $(\mathrm{P} ; \mathrm{mm})$, mean annual temperature or temperature range $\left(T_{\mathrm{Air}} ;{ }^{\circ} \mathrm{C}\right)$, leaf area index $\left(L A I ; \mathrm{m}^{22} \mathrm{~m}^{-2}\right)$, stand basal area $\left(\mathrm{m}^{2} \mathrm{ha}^{-1}\right)$ and mean stand tree height $\left(h_{\text {mean }}, \mathrm{m}\right)$, if available. Climate, biomass and site data for our study sites derived from Moser (2008)

a Aboveground biomass and $R_{\text {aboveground }}$ /biomass aboveground ratio are given

Growth and maintenance respiration

We found an average proportion of $R_{\mathrm{Sg}}$ from total $R_{\mathrm{S}}$ to vary between 10 and $14 \%$ along the elevation gradient, which appeared to be in the lower range of published data. Moreover, this low variability along the transect may indicate that no significant change in growth costs occurs with elevation. Ryan et al. (1994) reported values of $R_{\mathrm{Sg}}$ from total $R_{\mathrm{S}}$ of $18 \%$ in slow- and $46 \%$ in fast-growing tropical lowland tree species. In an afrotropical lowland forest, $20 \%$ of the $\mathrm{CO}_{2}$ released by tree stems was used for tissue construction (Meir and Grace 2002). However, the comparison with a recent study conducted along a tropical montane transect (Harris et al. 2008) supports the conclusion that our calculations of $R_{\mathrm{Sg}}$ are conservative. Harris et al. (2008) found the portion of $R_{\mathrm{Sg}}$ to range between 0 and $10 \%$ of total $R_{\mathrm{S}}$ for most of the tree species, except two lowland forest species (8-27\%). We explain the relatively low figures by the lower growth rates found at montane sites compared to lowland forests. Harris et al. (2008) reported stem diameter increment rates between 0.24 and $0.55 \mathrm{~cm} \mathrm{year}{ }^{-1}$ for the two lowland tree species and $0.03 \mathrm{~cm}$ year ${ }^{-1}$ for the elfin forest tree species. Along our transect, mean stem increment rates from the measured trees decreased from $0.55 \mathrm{~cm}_{\text {year }}{ }^{-1}$ at $1,050 \mathrm{~m}$ to $0.10 \mathrm{~cm}$ year $^{-1}$ at $3,050 \mathrm{~m}$ (Table 3 ).

A different picture is found for coarse roots. In parallel with the five-fold increase in coarse root growth from 1,050 to $3,050 \mathrm{~m}$, the fraction of $R_{\mathrm{Rg}}$ from total $R_{\mathrm{R}}$ increased markedly from $5 \%(1,050 \mathrm{~m})$ to $30 \%(3,050 \mathrm{~m})$ along our transect (Table 3), emphasising the increasing importance of root production with elevation. However, our estimates of $R_{\mathrm{Rg}}$ were based on very few $\mathrm{CO}_{2}$ efflux records from roots with diameters between 1 and $4 \mathrm{~cm}$, while the estimates of coarse root biomass production were based on woody roots with diameters between 3 and $32 \mathrm{~cm}$ (Moser 2008). Therefore, our calculated values can only provide an approximation of the actual amount of $R_{\mathrm{Rg}}$. 
We could not find any significant relationship between $R_{\text {Sm }}$ and tissue $\mathrm{N}$ content at our sites (data not shown), which was in contrast to several reports (e.g. Waring et al. 1985; Ryan 1990, 1991; Reich et al. 2008). Maintenance respiration has often been related to sapwood $\mathrm{N}$ content (e.g. Vose and Ryan 2002), which contains more $\mathrm{N}$ than hardwood (e.g. Bosc et al. 2003). For our tissue $\mathrm{N}$ analysis we used the entire stem core samples including sapwood and hardwood, which could have resulted in a certain dilution of the tissue $\mathrm{N}$ content in relation to $R_{\mathrm{S}}$. Furthermore, we did not account for the possible effect of xylem sap flow delivering dissolved $\mathrm{CO}_{2}$ to, or transporting away respiratory $\mathrm{CO}_{2}$ from, the point of measurement of internal pathways of $\mathrm{CO}_{2}$ in the plant. However, sap flux density measured at 1,950-1,975 $\mathrm{m}$ a.s.l. was very low in comparison to other tropical species under humid conditions and increased considerably during dry periods (Motzer et al. 2005). We could suspect then that the effect of transported $\mathrm{CO}_{2}$ in the sap flow could play a role during dry conditions and could have biased the correlation analysis.

\section{Scaling $R_{\mathrm{S}}$ and $R_{\mathrm{R}}$}

In terms of standing stem $\mathrm{C}$ stocks and extrapolated annual $R_{\mathrm{S}}$, the premontane site $(1,050 \mathrm{~m})$ was similar to a wet tropical lowland forest in Costa Rica (Ryan et al. 1994; Cavaleri et al. 2006; Table 4). Along a tropical montane transect in Puerto Rico, annual wood C efflux decreased from $737 \mathrm{~g} \mathrm{C} \mathrm{m}^{-2}$ ground area year ${ }^{-1}$ in a lowland forest at $100 \mathrm{~m}$ a.s.1. to $210 \mathrm{~g} \mathrm{C} \mathrm{m}^{-2}$ ground area $\mathrm{s}^{-1}$ in an elfin type forest at 1,050 m elevation (Harris et al. 2008). These figures largely exceed values scaled from our data along a tropical montane transect in Ecuador. However, stand-level extrapolation included estimates of branch respiration in the study of Harris et al. (2008), which was assumed to be equal to the measured $R_{\mathrm{S}}$ per unit bark surface. In addition, Harris et al. (2008) restricted their measurements to mostly one dominant tree species per elevation plot, which was considered representative for all species growing at this elevation. Annual $R_{\mathrm{S}}$ at $1,890 \mathrm{~m}$ was slightly lower than data reported for broadleaved temperate forests (Table 4). Annual $R_{\mathrm{S}}$ at 3,050 $\mathrm{m}$ was even lower than found for other sites with low aboveground productivity such as semi-arid shrub forests in the Sahel zone (Levy and Jarvis 1998) or a Canadian boreal forest (Lavigne and Ryan 1997). Discrepancies between our results from TMFs and the results from temperate, boreal and (sub-) tropical forests may also be a consequence of the use of different up-scaling procedures (e.g. Levy and Jarvis 1998; Damesin et al. 2001; Meir and Grace 2002; Cavaleri et al. 2006). On the other hand, the decline in annual $R_{\mathrm{S}}$ along our gradient was accompanied by similar annual amounts of $R_{\mathrm{R}}$ at 1,050 and $3,050 \mathrm{~m}$.
At 3,050 m, the lower specific rates of $R_{\mathrm{R}}$ were compensated for by a high coarse root biomass stock (Moser 2008). The shift in $\mathrm{C}$ allocation might be less pronounced in the Sahel shrub site and the Canadian boreal forest, which might partly explain the unexpectedly large gap.

\section{C use efficiency}

At the ecosystem level, CUE gives the fraction of $\mathrm{C}$ invested in growth relative to the total amount of $\mathrm{C}$ assimilated (i.e. ratio of net primary production to gross primary production). We calculated a CUE at the stem level of 0.46 and a coarse root CUE of 0.17 at $1,050 \mathrm{~m}$, while an opposite relationship was found at 3,050 m, where stem CUE was 0.16, whereas coarse root CUE was 0.55 (Table 3). Low CUE values could be indicative for several constraining factors such as low temperature, low radiation input due to frequent cloud cover and restricted nutrient availability, all of which seriously hamper the supply of assimilates for biomass production. The upper montane forests are thought to be primarily limited by $\mathrm{N}$ shortage (Leuschner et al. 2007; Soethe et al. 2007), supported by decreasing leaf and root tissue $\mathrm{N}$ contents along the gradient (Graefe et al. 2008). Plants growing in nutrient-poor soils usually show high nutrient use efficiencies. A high CUE of the coarse roots at 3,050 m seems to reflect that an economic $\mathrm{C}$ use for root anchorage and nutrient storage are priority tasks in this primarily $\mathrm{N}$-limited environment (Soethe et al. 2006). A preferential C investment into stem growth and respiration in the premontane forest is an expression of the more favourable growth conditions and a more fierce competition for light at $1,050 \mathrm{~m}$.

In the study area, Motzer et al. (2005) observed high sensitivity of canopy trees at 1,950-1,975 $\mathrm{m}$ a.s.l. to vapour pressure deficit and photosynthetic active radiation. Both climatic factors equally explained $50-52 \%$ of the variation in stomatal conductance. Wind played an additional role in the control of stomatal response and potentially decoupled canopy areas from the atmospheric evaporative demand. Furthermore, incident sunflecks in the sub-canopy likely increase stomatal conductance. All these observations clearly point to a high sensitivity of TMFs in response to environmental variation. Given that apparent rates of standlevel photosynthetic $\mathrm{C}$ gain declined with elevation (A. Zach, unpublished data) and that woody tissue $\mathrm{CO}_{2}$ efflux is generally higher in shoots than in roots in our tree sample, our data indicate a possible $\mathrm{C}$ supply limitation rather than temperature-mediated metabolic activity controlling CUE with increasing altitude. Under high-elevation grasslands, belowground $\mathrm{C}$ allocation and root growth was primarily controlled by radiation and hence carbohydrate supply, while plants were acclimated to the low temperature (Fitter et al. 1998). In our study, belowground $\mathrm{C}$ allocation is 
accompanied by increasing root CUE towards higher elevations, suggesting that substrate limitation is restricting soil resource uptake and hence productivity.

Contrary to our expectations, the results of this study clearly indicate that temperature is not the major driving factor for $R_{\mathrm{S}}$ and $R_{\mathrm{R}}$ along the elevation gradient. Other factors like radiation and wind or the interaction of both may be more important for the $\mathrm{CO}_{2}$ efflux by limiting carbohydrate supply. If both $R_{\mathrm{S}}$ and $R_{\mathrm{R}}$ indeed responded to changes in the light regime rather than to temperature, changes in the cloud cover would have serious impacts on $\mathrm{C}$ allocation patterns in TMFs. Further investigation should focus on the effects of other climatic factors, not only on $\mathrm{CO}_{2}$ efflux but also on the primary productivity of tropical mountain forests to test the hypothesis of a limiting substrate for respiration.

Acknowledgments We thank the Ministerio del Ambiente LojaZamora for granting the research permit, and the Fundación Científica San Francisco (Nature and Culture International) for ongoing support at the Estación Científica San Francisco. We thank Gerald Moser (University of Gottingen) for contributing data on climate and general stand characteristics. This study was funded by the DFG (German Science Foundation) through a grant to the Research Unit 402 (Functionality in a Tropical Mountain Rainforest, subproject B6). We declare that this work complies with the current laws of Ecuador.

Open Access This article is distributed under the terms of the Creative Commons Attribution Noncommercial License which permits any noncommercial use, distribution, and reproduction in any medium, provided the original author(s) and source are credited.

\section{References}

Amthor JS (2000) The McCree-de Wit-Penning de Vries-Thornley respiration paradigms: 30 years later. Ann Bot 86:1-20

Atkin OK, Holly C, Ball MC (2000) Acclimation of snow gum (Eucalyptus pauciflora) leaf respiration to seasonal and diurnal variations in temperature: the importance of changes in capacity and temperature sensitivity of respiration. Plant Cell Environ 23:15-26

Beck E, Müller-Hohenstein K (2001) Analysis of undisturbed and disturbed tropical mountain forest ecosystems in Southern Ecuador. Erde 132:1-8

Beck E, Bendix J, Kottke I, Makeschin F, Mosandl R (2008) Gradients in a tropical mountain ecosystem of Ecuador. Ecological studies vol 198. Springer, Heidelberg

Bendix J, Homeier J, Ortiz EC, Emck P, Breckle SW, Richter M, Beck E (2006) Seasonality of weather and tree phenology in a tropical evergreen mountain rain forest. Int $\mathrm{J}$ Biometeorol 50:370-384. doi:10.1007/s00484-006-0029-8

Bosc A, Grandcourt A, Loustau D (2003) Variability of stem and branch maintenance respiration in a Pinus pinaster tree. Tree Physiol 23:227-236

Bräuning A, von Schnakenburg P, Volland-Voigt F, Peters T (2008) Seasonal growth dynamics and its climate forcing in a tropical mountain rain forest in southern Ecuador. TRACE-tree rings in Archaeology. Climatol Ecol 6:27-30
Bruijnzeel LA, Veneklaas EJ (1998) Climatic conditions and tropical montane forest productivity: the fog is not lifted yet. Ecology 79:3-9

Bryla DR, Bouma TJ, Hartmond U, Eissenstat DM (2001) Influence of temperature and soil drying on respiration of individual roots in citrus: integrating greenhouse observations into predictive model for the field. Plant Cell Environ 24:781-790

Burton AJ, Pregitzer KS (2003) Field measurements of root respiration indicate little to no seasonal temperature acclimation for sugar maple and red pine. Tree Physiol 23:273-280

Cannell MGR, Thornley JHM (2000) Modelling the components of plant respiration: some guiding principles. Ann Bot 85:45-54

Cavaleri MA, Oberbauer SF, Ryan MG (2006) Wood $\mathrm{CO}_{2}$ efflux in a primary tropical rain forest. Glob Change Biol 12:2442-2458. doi:10.1111/j.1365-2486.2006.01269.x

Chambers JQ, Tribuzy ES, Toledo LC, Crispim BF, Higuchi N, Dos Santos J, Araújo AC, Kruijt B, Nobre AS, Trumbore SE (2004) Respiration from a tropical forest ecosystem: partitioning of sources and low carbon use efficiency. Ecol Appl 14:72-88

Damesin C, Ceschia E, Le Groff N, Ottorini JM, Dufrene E (2001) Stem and branch respiration of beech: from tree measurements to estimations at the stand level. New Phytol 153:159-172

Desrochers A, Landhäusser SM, Liefers VJ (2002) Coarse and fine root respiration in aspen (Populus tremuloides). Tree Physiol 22:725-732

Dewar RC, Medlyn BE, McMurtrie RE (1999) Acclimation of the respiration/photosynthesis ratio to temperature: insights from a model. Glob Change Biol 5:615-622

Edwards NT, Shugart HH Jr, McLaughlin SB, Harris WF, Reichle DE (1980) Carbon metabolism in terrestrial ecosystems. Ecology evolution and systematics 4: 97-115. In: Reichle DE (ed) Dynamic properties of forest ecosystems (International Biological Programme vol 23). Cambridge University Press, Cambridge

Ekblad A, Högberg P (2001) Natural abundance of ${ }^{13} \mathrm{C}$ in $\mathrm{CO}_{2}$ respired from forest soils reveals speed link between tree photosynthesis and root respiration. Oecologia 127:305-308. doi:10.1007/s004420100667

Fitter AH, Graves JD, Self GK, Brown TK, Bogie DS, Taylor K (1998) Root production, turnover and respiration under two grassland types along an altitudinal gradient: influence of temperature and solar radiation. Oecologia 114:20-30

Graefe S, Hertel D, Ch Leuschner (2008) Estimating fine root turnover in tropical forests along an elevation transect using minirhizotrons. Biotropica 40:536-542. doi:10.1111/j.17447429.2008.00419.x

Graham EA, Stephen SM, Kitajima K, Phillips NG, Wright SJ (2003) Cloud cover limits net $\mathrm{CO}_{2}$ uptake and growth of a rainforest tree during tropical rainy seasons. PNAS 100:572-576. doi: 10.1073_pnas.0133045100

Harris NL, Hall CAS, Lugo AE (2008) Estimates of species- and ecosystem-level respiration of woody stems along an elevation gradient in the Luquillo Mountains, Puerto Rico. Ecol Modell 216:253-264. doi:10.1016/j.ecolmodel.2008.04.008

Hartley IP, Armstrong AF, Murthy R, Barron-Gafford G, Ineson P, Atkin OK (2006) The dependence of respiration on photosynthetic substrate supply and temperature: integrating leaf, soil and ecosystem measurements. Glob Change Biol 12:1-15. doi: 10.1111/j.1365-2486.2006.01214.x

Lavigne MB, Ryan MG (1997) Growth and maintenance respiration rates of aspen, black spruce and jack pine stems ate northern and southern BOREAS sites. Tree Physiol 17:543-551

Leuschner C, Moser G, Bertsch C, Röderstein M, Hertel D (2007) Large altitudinal increase in the tree root/shoot ratio in tropical mountain forests of Ecuador. Basic Appl Ecol 8:219-230. doi: 10.1026/j.baae.2006.02.004 
Levy PE, Jarvis PG (1998) Stem $\mathrm{CO}_{2}$ fluxes in two Sahelian shrub species (Guiera sengalensis and Combretum micranthum). Funct Ecol 12:107-116

Loveys BR, Atkinson LJ, Sherlock DJ, Roberts RL, Fitter AH, Atkin OK (2003) Thermal acclimation of leaf and root respiration: an investigation comparing inherently fast- and slow-growing plant species. Glob Change Biol 9:895-910

Meir P, Grace J (2002) Scaling relationship for woody tissue respiration in two tropical rain forests. Plant Cell Environ 25:963-973

Moser G (2008) Elevation effects on key processes of carbon cycling in South Ecuadorian mountain forests. PhD dissertation, Department of Plant Ecology, University of Göttingen, Göttingen, Germany.

http://webdoc.sub.gwdg.de/diss/2008/moser/moser.pdf

Motzer T, Munz N, Küppers M, Schmitt D, Anhuf D (2005) Stomatal conductance, transpiration and sap flow of tropical montane rain forest trees in the southern Ecuadorian Andes. Tree Physiol 25:1283-1293

Penning de Vries FWT (1974) Substrate utilization and respiration in relation to growth and maintenance in higher plants. J Agric Sci 22:40-44

Penning de Vries FWT (1975) The use of assimilates in higher plants. In: Cooper JP (ed) Photosynthesis and productivity in different environments. Cambridge University Press, New York, pp 459480

Poorter H (1994) Construction costs and payback time of biomass: a whole plant perspective. In: Roy J, Granier E (eds) A whole plant perspective on carbon-nitrogen interactions. SPB, The Hague, pp 111-127

Reich PB, Tjoelker MG, Pregitzer KS, Wright IJ, Oleksyn J, Machado JL (2008) Scaling of respiration to nitrogen in leaves, stems and roots of higher land plants. Ecol Lett 11:793-801. doi: 10.1111/j.1461-0248.2008.01185.x

Ryan MG (1990) Growth and maintenance respiration in stems of Pinus contorta and Pinus engelmannii. Can J For Res 20:48-57

Ryan MG (1991) Effect of climate change on plant respiration. Ecol Appl 1:157-167

Ryan MG, Hubbard RM, Clark DA, Sanford RL Jr (1994) Woodytissue respiration of Simarouba amara and Minquartia guinensis, two wet forest trees with different growth habits. Oecologia 100:213-220

Ryan MG, Lavigne MB, Gower ST (1997) Annual carbon costs of autotrophic respiration in boreal forest ecosystems in relation to species and climate. J Geophy Res 102(28):871-883

Soethe N, Lehmann J, Engels C (2006) Root morphology and anchorage of six native tree species from a tropical montane forest and an elfin forest in Ecuador. Plan Soil 279:173-185. doi: 10.1007/S11104-006-9044-0

Soethe N, Lehmann J, Engels C (2007) Carbon and nutrient stocks in roots of forests at different altitudes in the Ecuadorian Andes. J Trop Ecol 23:319-328. doi:10.1017/S0266467407004002

Sprugel DG (1990) Components of woody-tissue respiration in young Abies amabilis trees. Trees 4:88-98

Teskey RO, McGuire MA (2002) Carbon dioxide transport in xylem causes errors in estimation of rates of respiration in stems and branches of trees. Plant Cell Environ 25:1571-1577

Teskey RO, McGuire MA (2007) Measurement of stem respiration of sycamore (Plantanus occidentalis $\mathrm{L}$.) trees involves internal and external fluxes of $\mathrm{CO}_{2}$ and possible transport of $\mathrm{CO}_{2}$ from roots. Plant Cell Environ 30:570-579. doi:10.1111/j.1365-3040.2007. 01649.x

Unger M (2005) Veränderung blattchemischer und -morphologischer Eigenschaften von Bäumen im tropischen Regenwald Südecuadors in Abhängigkeit vom Strahlungsregime in einem Höhentransekt. Diploma thesis, Department of Plant Ecology, University of Göttingen, Göttingen, Germany

Vose JM, Ryan MG (2002) Seasonal respiration of foliage, fine roots, and woody tissue in relation to growth, tissue $\mathrm{N}$, and photosynthesis. Glob Change Biol 8:182-193

Waring RH, McDonald JS, Larssen S, Ericsson T, Wiren A, Arwidsson E, Ericsson A, Lohammar T (1985) Differences in chemical composition of plants grown at constant relative growth rates with stable mineral nutrition. Oecologia 66:157-160

Williams K, Percival F, Merino J, Mooney HA (1987) Estimation of tissue construction cost from heat of combustion and organic nitrogen content. Plant Cell Environ 16:539-546

Zach A, Horna V, Leuschner C (2008) Elevational change in woody tissue $\mathrm{CO}_{2}$ efflux rates in a tropical mountain rainforest in southern Ecuador. Tree Physiol 28:67-74 